\title{
Optical Studies on Extraction of Some Transition Metal Cations Through Liquid Membrane Containing 1-Phenylazonaphth-2-OI as lonophore
}

\author{
KIRTI YADAV $^{1 *}$, VANDANA SHARMA ${ }^{2}$, P.C. CHOYAL ${ }^{3}$ and VIJAY R. CHOUREY ${ }^{2}$
}

${ }^{1}$ Chemistry Department, Kasturbagram Rural Institute, Indore, India.

${ }^{2}$ Govt. Autonomous Holkar Science College, Indore (M.P.) 452001, India.

${ }^{3}$ Govt. P.G. College Dhar (M.P.) India.

${ }^{*}$ Corresponding author E-mail: kirtiyadav74@gmail.com

http://dx.doi.org/10.13005/ojc/330463

(Received: April 18, 2017; Accepted: june 04, 2017)

\begin{abstract}
Extraction of metal cation through liquid membrane is one of the important application of supramolecular chemistry. This work investigates the use of synthetic carrier (ionophore) for the extraction of transition metal cations. In this work effect of light on extraction of metal cations through chromophoric ionophore have been tested. For this purpose, a non-cyclic ionophore,1phenylazonaphth-2-ol has been used to extract transition metal cations $\left(\mathrm{Co}^{2+}, \mathrm{Ni}^{2+}, \mathrm{Cu}^{2+}\right.$ and $\left.\mathrm{Zn}^{2+}\right)$. Chloroform is used as a solvent. The extracted amount of metal cations depends mainly upon the structure and the concentration of the ionophore and also on the concentration of metal ions. These studies were focused on the capacity of the ionophore to extract metal cation from an aqueous phase into an Organic phase by complexation. On comparing the results of extraction of metal cations $\left(\mathrm{Co}^{2+}, \mathrm{Ni}^{2+}, \mathrm{Cu}^{2+}\right.$ and $\left.\mathrm{Zn}^{2+}\right)$ with ionophores1-phenylazonaphth-2-olin the presence of artificial light source $(100 \mathrm{~W})$ and natural light it is observed that these ionophores exhibit the photo responsive properties.
\end{abstract}

Keywords: Liquid membrane extraction, Non-cyclic ionophore, Transition metal cations, Photo responsive properties.

\section{INTRODUCTION}

Dyes ${ }^{1}$ have been extensively used in such as in ink-jet printing, imagining and in electronics. These required functional dyes which are able to form organized supramolecular assemblies ${ }^{2}$, the properties of which can be controlled as a function of self-assembly process. Supramolecular control dye arrangement is important for providing the improved performance of existing devices and to create new dye-based materials with tunable optical and electronic properties. Now a dyes considerable efforts are being made towards the modification of the structure of organic dyes in the direction of the 
self-organization. These studies have generated a wealth of knowledge in the designing of variety of materials and complexes with intriguing properties.

The field of supramolecular chemistry has brought to light of new binding sites with improved selectivity. Logically, the idea of coupling these ionophores to chromophores or fluorophores emerged some years later, leading to the so-called chromoionophore and fluoroionophore ${ }^{3}$. The chromoand fluoro-ionophores form a particularly interesting class of probes since they can combine recognition properties with optical transduction, i.e. changing colour or fluorescence ${ }^{4}$.

\section{EXPERIMENTAL}

\section{Extraction studies in the presence of artificial visible light source}

To study the special effect of artificial light radiation on the extraction processes, the experiments have been carried out in the following two conditions:

- Extraction in presence of artificial visible light source (100W tungsten filament).

- In total darkness.

These studies have been performed to assess the effect of light on the extraction of metal ions in the presence of visible light source.

In this method $10 \mathrm{~mL}$ of aqueous metal salt solution was vigorously stirred with $10 \mathrm{~mL}$ of ionophore solution in organic solvent (chloroform) in a small beaker. The solution was magnetically stirred using Teflon coated capsule. The beaker was covered by the paraffin to minimize the rate of evaporation. The photo irradiation was carried out using visible light source (100W tungsten filament) and intensity of light were measured by ms6610 Lux meter. This process was continued up to 4 hours. After well stirring, the mixture was allowed to stand for 5 minutes for the separation of two phases. The depleted aqueous phase was removed and the metal content was analyzed by volumetric method. The amount of metal cation extracted by ionophore was measured by their difference in aqueous phase before and after extraction (tables- 1 to 4 ).
The extraction experiments were also carried out in complete darkness (absence of light).

\section{RESULTS AND DISCUSSION}

\section{Extraction studies in the presence of artificial visible light source}

To study the effect of light radiation on extraction process the experiments have been carried out at two different concentrations of ionophore (1.0x $10^{-3} \mathrm{M}$ and $1.0 \times 10^{-4} \mathrm{M}$ ), in the following conditions.

1. Extraction in the presences of artificial visible light source (100 W tungsten filament)

2. In the natural light(3). In total darkness

The results of extraction of metal cations $\left(\mathrm{Co}^{2+}, \mathrm{Ni}^{2+}, \mathrm{Cu}^{2+}\right.$ and $\left.\mathrm{Zn}^{2+}\right)$ with ionophore1phenylazonaphth-2-olare listed in the tables (1 to 4 ).

On comparing the results of extraction of metal cations $\left(\mathrm{Co}^{2+}, \mathrm{Ni}^{2+}, \mathrm{Cu}^{2+}\right.$ and $\left.\mathrm{Zn}^{2+}\right)$ with ionophore1-phenylazonaphth-2-olin the presence of artificial light source (100W) and natural light it is observed that this ionophore exhibit the photo responsive properties.

The experiments were carried out at two different light intensities (126×10 Lux and 73×10 Lux) as measured by Lux meter ${ }^{5}$. The results indicate that $73 \times 10$ Lux is suitable intensity of light for extraction of metal cations with ionophore1-phenylazonaphth-2-ol shows higher extraction capacity at 126×10 Lux.

The observed trend of extraction of selected metal cations $\left(\mathrm{Co}^{2+}, \mathrm{Ni}^{2+}, \mathrm{Cu}^{2+}\right.$ and $\left.\mathrm{Zn}^{2+}\right)$ by ionophore1-phenylazonaphth-2-ol in the presence of artificial light source and in natural light is found different.

The observed trend of extraction of selected metal cations by ionophores 1 -phenylazonaphth2-ol in the presence of artificial light source (100W tungsten filament) is $\mathrm{Zn}^{2+}>\mathrm{Ni}^{2+}>\mathrm{Cu}^{2+}$ while $\mathrm{Co}^{2+}$ does not shows extraction in the presence of light source. The observed trend of extraction of selected metal cations by ionophore1-phenylazonaphth-2-ol in the natural light is $\mathrm{Co}^{2+}>\mathrm{Ni}^{2+}>\mathrm{Cu}^{2+}$ while $\mathrm{Zn}^{2+}$ does not shows extraction in the natural light with ionophore 1-phenylazonaphth-2-ol (table- 2). 


\section{Optical effect on extraction}

Table: 1Amount of metal ion extracted after 4 hours with ionophore (concentration1.0 $\times 10^{-3} \mathrm{M}$ ) in the absence and presence of artificial light source $(100 \mathrm{~W})$ at two different intensities in chloroform

Concentration of metal salt $=1.0 \times 10^{-1} \mathrm{M}$, Concentration of ionophore $=1.0 \times 10^{-3} \mathrm{M}$ Intensity of light $=126 \times 10$ Lux, Intensity of light $=73 \times 10$ Lux

\begin{tabular}{lccc}
\hline Metal Salts & $\begin{array}{c}\text { Amount of cation } \\
\text { extracted (in gm/ L) } \\
\text { by ionophore }\end{array}$ & $\begin{array}{c}\text { Amount of cation } \\
\text { extracted (in gm/ L) } \\
\text { by ionophore at } \\
\text { 126×10 Lux }\end{array}$ & $\begin{array}{c}\text { Amount of cation } \\
\text { extracted (in gm/L) } \\
\text { by ionophores at } \\
73 \times 10 \text { Lux }\end{array}$ \\
\hline & $\begin{array}{c}\text { (absence of } \\
\text { light source) }\end{array}$ & (Presence of light source)100 W bulb \\
& 2.9103 & - & - \\
$\mathrm{Co}\left(\mathrm{NO}_{3}\right)_{2}$ & 2.8085 & - & 8.4255 \\
$\mathrm{NiSO}$ & 4.8320 & 4.8320 & 4.8320 \\
$\mathrm{Cu}\left(\mathrm{NO}_{3}\right)_{2}$ & - & 14.3770 & 20.1278 \\
$\mathrm{ZnSO}$ & & & \\
\hline
\end{tabular}

Table: 2 Comparative amount of metal ion extracted after 4 hours with ionophore (conc. $1.0 \times 10^{-4} \mathrm{M}$ ) in the absence and presence of artificial light source $(100 \mathrm{~W})$ at two different intensities in chloroform

Concentration of metal salt $=1.0 \times 10^{-1} \mathrm{M}$, Concentration of ionophore $=1.0 \times 10^{-4} \mathrm{M}$ Intensity of light $=126 \times 10$ Lux, Intensity of light $=73 \times 10$ Lux

\begin{tabular}{lccc}
\hline Metal Salts & $\begin{array}{c}\text { Amount of cation } \\
\text { extracted (in } \mathbf{~ g m / ~ L ) ~} \\
\text { by ionophore }\end{array}$ & $\begin{array}{c}\text { Amount of cation } \\
\text { extracted (in gm/ L) } \\
\text { by ionophore at } \\
\mathbf{1 2 6 \times 1 0 ~ L u x ~}\end{array}$ & $\begin{array}{c}\text { Amount of cation } \\
\text { extracted (in gm/L) } \\
\text { by ionophores at } \\
\mathbf{7 3 \times 1 0 ~ L u x ~}\end{array}$ \\
\cline { 2 - 4 } & $\begin{array}{c}\text { (absence of } \\
\text { light source) }\end{array}$ & (Presence of light source)100 W bulb \\
\hline $\mathrm{Co}\left(\mathrm{NO}_{3}\right)_{2}$ & 17.4618 & - & - \\
$\mathrm{NiSO}$ & 16.8510 & - & 5.6170 \\
$\mathrm{Cu}\left(\mathrm{NO}_{3}\right)_{2}$ & 14.4960 & 4.8320 & 2.4160 \\
$\mathrm{ZnSO}_{4}$ & - & 14.3770 & 17.2524 \\
\hline
\end{tabular}


Table 3: Comparative amount of metal ion extracted after 4 hours with ionophore (conc. $1.0 \times 10^{-3} \mathrm{M}$ ) in the absence and presence of artificial light source (100 W bulb) at two different intensities in chloroform

Concentration of metal salt $=1.0 \times 10^{-2} \mathrm{M}$, Concentration of ionophore $=1.0 \times 10^{-3} \mathrm{M}$ Intensity of light $=126 \times 10$ Lux, Intensity of light $=73 \times 10$ Lux

\begin{tabular}{|c|c|c|c|}
\hline \multirow[t]{2}{*}{ Metal Salts } & \multirow{2}{*}{$\begin{array}{l}\text { Amount of cation } \\
\text { extracted (in gm/ L) } \\
\text { by ionophore } \\
\text { (absence of } \\
\text { light source) }\end{array}$} & $\begin{array}{c}\text { Amount of cation } \\
\text { extracted (in } \mathrm{gm} / \mathrm{L} \text { ) by } \\
\text { ionophore at } 126 \times 10 \mathrm{Lux}\end{array}$ & $\begin{array}{l}\text { Amount of cation } \\
\text { extracted (in } \mathrm{gm} / \mathrm{L} \text { ) by } \\
\text { ionophore at } 73 \times 10 \mathrm{Lux}\end{array}$ \\
\hline & & \multicolumn{2}{|c|}{ (Presence of light source100 W bulb) } \\
\hline $\mathrm{Co}\left(\mathrm{NO}_{3}\right)_{2}$ & 1.1641 & - & 0.2913 \\
\hline $\mathrm{NiSO}_{4}$ & - & 3.3702 & 1.1234 \\
\hline $\mathrm{Cu}\left(\mathrm{NO}_{3}\right)_{2}$ & 4.8320 & 2.4160 & 0.7248 \\
\hline $\mathrm{ZnSO}_{4}$ & 1.7252 & 3.4504 & 1.1501 \\
\hline
\end{tabular}

Table 4: Comparative amount of metal ion extracted after 4 hours with ionophore (conc. $1.0 \times 10^{-4} \mathrm{M}$ ) in the absence and presence of artificial light source $(100 \mathrm{~W}$ bulb) at two different intensities in chloroform

Concentration of metal salt $=1.0 \times 10^{-2} \mathrm{M}$, Concentration of ionophore $=1.0 \times 10^{-4} \mathrm{M}$ Intensity of light $=126 \times 10 \mathrm{Lux}, \quad$ Intensity of light $=73 \times 10 \mathrm{Lux}$

\begin{tabular}{lccc}
\hline Metal Salts & $\begin{array}{c}\text { Amount of cation } \\
\text { extracted (in gm/ L) } \\
\text { by ionophore }\end{array}$ & $\begin{array}{c}\text { Amount of cation } \\
\text { extracted (in gm/ L) by } \\
\text { ionophore at 126 } \times 10 \text { Lux }\end{array}$ & $\begin{array}{c}\text { Amount of cation } \\
\text { extracted (in gm/L) by } \\
\text { ionophores at } \mathbf{7 3} \times \mathbf{1 0} \text { Lux }\end{array}$ \\
\cline { 2 - 4 } & $\begin{array}{c}\text { (absence of } \\
\text { light source) }\end{array}$ & (Presence of light source)100 W bulb \\
\hline $\mathrm{Co}\left(\mathrm{NO}_{3}\right)_{2}$ & 2.9103 & 0.2910 & - \\
$\mathrm{NiSO}$ & - & 4.2127 & 2.8085 \\
$\mathrm{Cu}\left(\mathrm{NO}_{3}\right)_{2}$ & - & 2.4160 & 2.1744 \\
$\mathrm{ZnSO}_{4}$ & - & 4.3131 & 2.5878 \\
\hline
\end{tabular}

On the basis of results it can be concluded that the effect of light radiation on extraction process are opposite from the results obtained by the extraction process in the natural light source. The presence of chromophoric mono azo $(-\mathrm{N}=\mathrm{N}-)$ and diazo moiety in the ionophore1-phenylazonaphth2-ol attributed for the same.

The trans- isomer of azobenzene can be photomerized to the cis-isomer, which can be converted thermally back to the trans form again ${ }^{11}$.
The isomerization is completely reversible, free from side reactions ${ }^{6}$. It can be concluded that in the presence of artificial light source these ionophore (1-phenylazonaphth-2-ol) form cis configuration and shows more selectivity towards the $\mathrm{Zn}^{2+}$ ions

The extraction experiments have also been carried out in the complete darkness. Furthermore, no any progress in extraction process is observed. These results also support that ionophore is photoresponsive in nature ${ }^{7 s}$. 


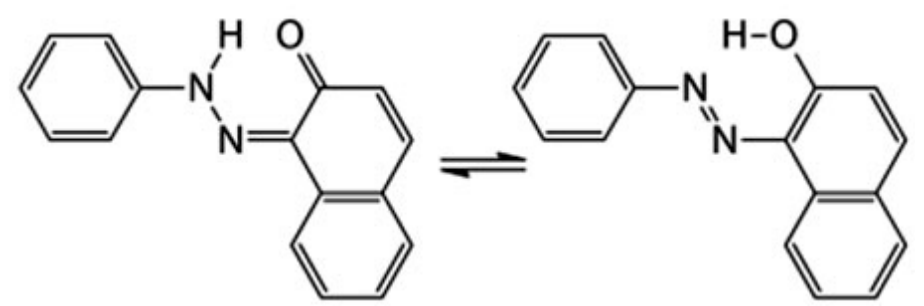

Fig.1: TransandCisgeometric isomers of azobenzene

\section{CONCLUSION}

lonophoreis better extractant for $\mathrm{Co}^{2+}$ and $\mathrm{Cu}^{2+}$ ions in the natural light. The selected ionophore shows better extraction selectivity for $\mathrm{Zn}^{2+}$ in the presence of artificial light source only.

On comparing the results of extraction of metal cations $\left(\mathrm{Co}^{2+}, \mathrm{Ni}^{2+}, \mathrm{Cu}^{2+}\right.$ and $\left.\mathrm{Zn}^{2+}\right)$ with ionophore1-phenylazonaphth-2-ol in the presence of artificial light source (100W tungsten filament) and natural light it is observed that these ionophores have photo responsive properties.

The extraction experiments have also been carried out in the complete darkness, but no progress in the extraction is observed.

\section{ACKNOWLEDGEMENTS}

The authors are thankful to Dr. Ruplekha Vyas, Professor and Head, Govt. Auto. Holkar Science College, Indore (M.P.), for providing laboratory facilities.

\section{REFERENCES}

1. Turback, A. F. ;J. Textile Research,1967, 37, 350.

2. Okamoto, K.; Chithra, P.; Richards, G. J.; Hill J. P.; Ariga, K. Int. J. Mol. Sci., 2009, 10, 1950.

3. Zolinger, H.; Iqbal, A. Color Chemistry: synthesis, properties and applications of organic dyes and pigments; $3^{\text {rd }}$ rev. ed.,2003.
4. Lehn, L. M.; Supramolecular Chemistry, VCH, Weinheim, Germany,1995.

5. Yadav, K.; Bende N.; Chourey, V. R. Int. J. Advance Research, 2014, 2(3), 488.

6. Mimrot, M.; Tomar, J.; Sharma, U.; Main Group Metal Chemistry, 2011, 31(6), 289.

7. Halabieh, R. H. El ;Mermut, O.; Barrett, C. J. Pure Appl. Chem., 2004, 76 (7-8), 1445, . 